\title{
Interpreting the results of early skin tests after perioperative anaphylaxis requires special attention: a case report and review of literature
}

\author{
Masaki Orihara $^{1} \mathbb{D} \cdot$ Tomonori Takazawa $^{2} \cdot$ Kazuhiro Nagumo $^{2} \cdot$ Shinya Sakamoto $^{1} \cdot$ Tatsuo Horiuchi $^{1}$ - Shigeru Saito ${ }^{1}$
}

Received: 1 April 2020 / Accepted: 23 May 2020 / Published online: 31 May 2020

(c) The Author(s) 2020

\begin{abstract}
Skin tests are the gold standard for detecting the culprit drug of anaphylaxis, and should ideally be performed after an interval of 4-6 weeks after the reaction to avoid false-negative results. However, when re-operation cannot be delayed and early allergy tests are necessary, special attention is required during subsequent anesthesia, because early skin tests tend to produce false-negative results. This report presents a case of rocuronium-induced anaphylaxis in which early skin tests showed negative results for all the drugs tested. The second anesthesia was safely performed by avoiding all the drugs used for the first anesthesia. Ultimately, skin tests and basophil activation tests (BATs) performed after re-operation demonstrated rocuronium as the drug responsible for anaphylaxis. We recommend performing BATs in addition to skin tests to improve the accuracy of diagnosis of anaphylaxis. In this report, we also discuss interpretation of the results of early skin tests and subsequent selection of drugs for anesthesia. After postponement of surgery due to anaphylaxis, we are often required to perform allergy tests at an early stage if re-operation cannot be delayed. In such cases, skin test results alone should not be used to guide subsequent anesthesia management to avoid recurrent anaphylaxis.
\end{abstract}

Keywords Anaphylaxis · Rocuronium · Skin test · Basophil activation test

\section{Introduction}

Masaki Orihara

masaki_ori@yahoo.co.jp

Tomonori Takazawa

takazawt@gunma-u.ac.jp

Kazuhiro Nagumo

nagumo-kazuhiro@kuh.biglobe.ne.jp

Shinya Sakamoto

sin03462@yahoo.co.jp

Tatsuo Horiuchi

m14702013@gunma-u.ac.jp

Shigeru Saito

shigerus@gunma-u.ac.jp

1 Department of Anesthesiology, Gunma University Graduate School of Medicine, 3-39-22, Showa-machi, Maebashi 371-8511, Japan

2 Intensive Care Unit, Gunma University Hospital, 3-39-15, Showa-machi, Maebashi 371-8511, Japan
Anaphylaxis is defined as a life-threatening systemic hypersensitivity reaction of sudden onset [1]. After the occurrence of anaphylaxis, allergologic assessment is essential to identify the causative agent and prevent recurrences [2]. Skin tests remain the gold standard for detection of the culprit drug, and should ideally be performed at an interval of 4-6 weeks after the reaction [2,3]. However, in some cases, surgery cannot be delayed for this long a period, and investigation must be done earlier. While recent guidelines suggest that skin tests can be performed immediately after a reaction $[4,5]$, several articles warn about the possibility of false-negative results, especially with early skin tests [6]. Although subsequent uneventful anesthesia is guaranteed as long as true-negative drugs are used, the use of drugs that are false negative in skin tests could result in a second severe anaphylactic reaction $[7,8]$. Thus, even if early skin test results are negative for all the drugs tested, special attention is required during the subsequent anesthesia.

Here, we describe a case of anaphylaxis in which early skin tests showed negative results for all the drugs tested, 
despite which all of these drugs were avoided during subsequent anesthesia and surgery. As a result, the surgery was successfully completed without recurrence of anaphylaxis.

\section{Case report}

This case was part of a prospective observational study approved by the institutional review board of Gunma University Hospital (ID: 1084) and registered with the University Hospital Medical Information Network Clinical Trials Registry (ID: 000022365). Written informed consent was obtained from the patient's parent prior to the tests.

A 19-year-old, 82-kg, 175-cm male was scheduled for open reduction and internal fixation for mandibular fracture. He had no past history of allergy or surgery. Anesthesia was induced with a 3- $-\mu \mathrm{g} / \mathrm{ml}$ target-controlled infusion of propofol and $80-\mathrm{mg}$ rocuronium. At the same time, continuous administration of remifentanil was started at the rate of $0.3 \mu \mathrm{g} / \mathrm{kg} / \mathrm{min}$. Immediately after anesthesia induction, he demonstrated skin erythema and wheals mainly in the anterior chest area. Although endotracheal intubation was successfully performed, his oxygen saturation decreased to approximately $80 \%$, together with the development of wheezing. The patient did not show any cardiovascular symptoms. Suspecting a possible allergic reaction or asthmatic attack, he was treated with $200-\mu \mathrm{g}$ salbutamol inhalation and intravenous injection of 6.6-mg dexamethasone, with subsequent improvement in respiratory symptoms. The surgery was, however, canceled and he was transferred to the intensive care unit, where he remained until his trachea was extubated $3 \mathrm{~h}$ after the event.

Since early surgery was necessary to prevent occlusal deficiency and trismus, surgery was rescheduled for
10 days after the event. Both skin prick tests (SPTs) and intradermal tests (IDTs) using all the drugs suspected to be the possible cause of anaphylaxis were performed eight days after the event, all of which showed negative reactions. Skin tests should ideally be performed a minimum of 4-6 weeks after the reaction to avoid false-negative results [9]. Since we considered the possibility of falsenegative results in skin tests, our second general anesthesia plan did not include any of the suspected offending drugs. The second anesthesia was induced with bolus intravenous injection of $12-\mathrm{mg}$ midazolam and $30-\mathrm{mg}$ pentazocine, and inhalation of $8 \%$ sevoflurane and $50 \%$ nitrous oxide. After successful endotracheal intubation, anesthesia was maintained with $2 \%$ sevoflurane and $60 \%$ nitrous oxide. The operation was successfully completed within $231 \mathrm{~min}$. The patient's postoperative course was uneventful and he was discharged home 14 days later.

Seven weeks after the episode, skin tests were performed with propofol, rocuronium and remifentanil. While SPTs showed a negative reaction to all the drugs tested, IDTs showed a positive reaction to only $50-\mu \mathrm{g} / \mathrm{ml}$ rocuronium (Table 1). We also performed basophil activation tests (BATs) on the same day as the skin tests, detailed methods for which are described elsewhere [10-12]. Briefly, CD203c was used as a marker to detect activated basophils using a flow cytometer (FACSCanto II; BD Biosciences, San Jose, CA). The patient's ratio of activated basophils was calculated and compared with that of a healthy male volunteer with no allergic skin test reaction to rocuronium. We confirmed a marked increase in the rate of activated basophils after stimulation with 10,000$\mu \mathrm{g} / \mathrm{ml}$ rocuronium. No such increase was observed after stimulation with any of the concentrations of rocuronium examined in the control individual (Fig. 1).

Table 1 Results of skin tests

\begin{tabular}{|c|c|c|c|c|c|c|c|c|}
\hline \multirow{3}{*}{ Drug } & \multicolumn{4}{|c|}{ First skin tests at 8 days after the reaction } & \multicolumn{4}{|c|}{$\begin{array}{l}\text { Second skin tests at } 7 \text { weeks after the } \\
\text { reaction }\end{array}$} \\
\hline & SPT & IDT & & & SPT & IDT & & \\
\hline & & & Wheal (mm) & Flare $(\mathrm{mm})$ & & & Wheal (mm) & Flare $(\mathrm{mm})$ \\
\hline Saline & - & - & & & - & - & & \\
\hline Histamine & + & + & 8 & 12 & + & + & 10 & 30 \\
\hline Propofol & - & - & & & - & - & & \\
\hline Rocuronium & - & - & & & - & + & 6 & 10 \\
\hline Remifentanil & - & - & & & - & - & & \\
\hline
\end{tabular}

Drug concentrations for SPTs: histamine $10 \mathrm{mg} / \mathrm{ml}$, propofol $0.1,1,10 \mathrm{mg} / \mathrm{ml}$, rocuronium $0.1,1,10 \mathrm{mg}$ / $\mathrm{ml}$, remifentanil $0.5,5,50 \mu \mathrm{g} / \mathrm{ml}$

Drug concentrations for IDTs: histamine $10 \mu \mathrm{g} / \mathrm{ml}$, propofol 0.01, 0.1, $1 \mathrm{mg} / \mathrm{ml}$, rocuronium $0.5,5,50 \mu \mathrm{g} /$ $\mathrm{ml}$, remifentanil $0.05,0.5,5 \mu \mathrm{g} / \mathrm{ml}$

$S P T$ skin prick test; $I D T$ intradermal test 


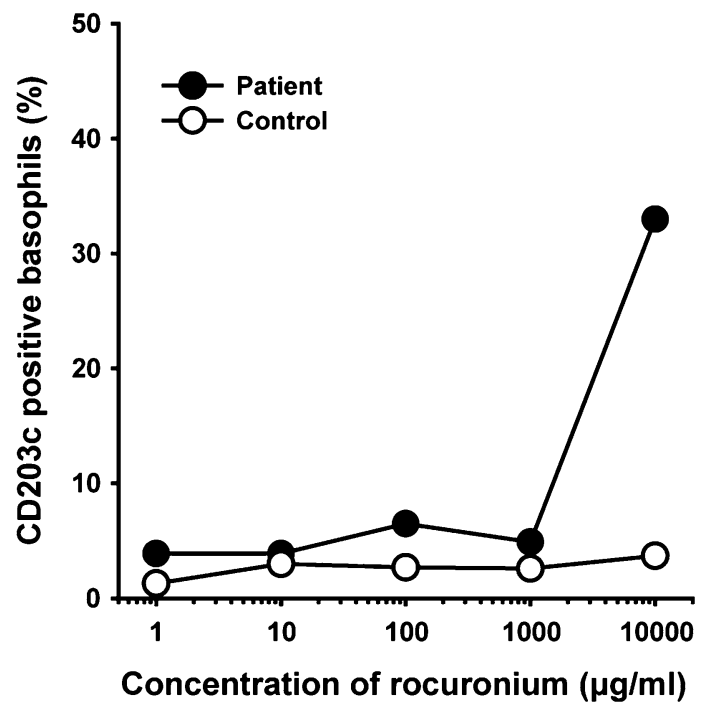

Fig. 1 Results of basophil activation tests. CD203c upregulation was evident in the patient with rocuronium-induced anaphylaxis (closed circles) as compared to a control individual (open circles)

\section{Discussion}

We report here a case of rocuronium-induced anaphylaxis in which the second anesthesia was safely performed by avoiding all the drugs used for the first anesthesia. Ultimately, skin tests and BATs performed after re-operation demonstrated that rocuronium was the drug responsible for anaphylaxis.

Skin tests are widely used to determine the culprit drug for an anaphylactic reaction during anesthesia. In general, skin tests allow accurate diagnosis of drug hypersensitivity in more than $70 \%$ of cases [13]. As already described, experts recommend performing skin tests 4-6 weeks after the reaction $[2,3,9]$.

Early allergy studies could be important when surgery is urgent. Often, surgery is discontinued or postponed in patients who develop a severe allergic reaction during anesthesia. When the surgery cannot be delayed, such as in patients with aggressive tumors or those who require emergency surgery, performing allergy tests soon after the event is inevitable $[6,14]$. In our case, due to the urgent need for surgery, we had to perform early skin tests. However, since we anticipated that the early skin test results would be equivocal, our second general anesthesia plan did not include any of the suspected offending drugs to prevent recurrence. When skin tests are carried out earlier than the recommended 4-6 weeks after anaphylaxis, the risk of false-negative results cannot be ruled out. Indeed, in a review of previous literature, we found five cases in which the first skin tests performed within three weeks of the reaction were negative for all culprit drugs tested [6, 15-17] (Table 2). In three of the five cases, surgery was suspended until second skin tests were performed at least six weeks after the reaction to identify the offending drug.

Table 2 Case reports in which the first skin tests performed within three weeks showed negative results for all suspected drugs

\begin{tabular}{|c|c|c|c|c|c|c|c|c|c|c|}
\hline \multirow{2}{*}{$\begin{array}{l}\text { Case } \\
\text { number }\end{array}$} & \multirow[t]{2}{*}{ Age } & \multirow[t]{2}{*}{ Sex } & \multirow[t]{2}{*}{ Procedure } & \multirow{2}{*}{$\begin{array}{l}\text { Culprit } \\
\text { drug }\end{array}$} & \multicolumn{2}{|c|}{ First skin tests } & \multicolumn{2}{|c|}{ Second skin tests } & \multirow{2}{*}{$\begin{array}{l}\text { Outcome of } \\
\text { subsequent } \\
\text { surgery }\end{array}$} & \multirow{2}{*}{$\begin{array}{l}\text { Refer- } \\
\text { ence } \\
\text { number }\end{array}$} \\
\hline & & & & & Delay & Results & Delay & Results & & \\
\hline 1 & 42 & $\mathrm{~F}$ & $\begin{array}{l}\text { Hysterectomy for } \\
\text { menorrhagia }\end{array}$ & $\begin{array}{l}\text { d-tubocur- } \\
\text { arine }\end{array}$ & 4 days & IDT - & 3 weeks & IDT $1: 1000+$ & Not described & 15 \\
\hline 2 & 44 & M & $\begin{array}{l}\text { Cervical discectomy } \\
\text { and fusion for cer- } \\
\text { vical myelopathy } \\
\text { and progressive } \\
\text { bilateral lower } \\
\text { extremity weak- } \\
\text { ness }\end{array}$ & Cefazolin & 6 days & SPT -, IDT - & 6 weeks & SPT $1 \mathrm{mg} / \mathrm{ml}+$ & Un eventful* & 16 \\
\hline 3 & 71 & M & $\begin{array}{l}\text { Revision of a knee } \\
\text { prosthesis }\end{array}$ & $\begin{array}{l}\text { Chlorhex- } \\
\text { idine }\end{array}$ & 6 days & SPT - & 11 weeks & $\begin{array}{l}\text { SPT } 1: 1+, \text { IDT } \\
1: 10,000+\end{array}$ & Uneventful* & 6 \\
\hline 4 & 58 & $\mathrm{~F}$ & $\begin{array}{l}\text { Intravaginal ultra- } \\
\text { sound examina- } \\
\text { tion for vaginal } \\
\text { bleeding }\end{array}$ & $\begin{array}{l}\text { Natural } \\
\text { rubber } \\
\text { latex }\end{array}$ & 12 days & SPT - & 3 months & $\mathrm{SPT}+$ & Not described & 17 \\
\hline 5 & 71 & M & $\begin{array}{l}\text { Hemicolectomy for } \\
\text { cecal carcinoma }\end{array}$ & $\begin{array}{c}\text { Rocuro- } \\
\text { nium }\end{array}$ & 20 days & $\begin{array}{l}\text { SPT slightly } \\
\text { suspicious, } \\
\text { IDT - }\end{array}$ & $\begin{array}{l}6 \text { weeks and } \\
5 \text { days }\end{array}$ & $\begin{array}{l}\text { SPT } 1: 1+, \text { IDT } \\
1: 100+\end{array}$ & Uneventful* & 6 \\
\hline
\end{tabular}

$F$ female; $M$ male; $S P T$ skin prick test; $I D T$ intradermal test

*After the first surgery was postponed, the subsequent surgery could be completed without any problem by avoiding the drugs that showed positive results in the second skin tests 
On the other hand, the causative drug was successfully identified by early skin tests in several cases [6, 18-23] (Table 3). In seven cases, skin tests performed between one and 14 days after the anaphylactic reaction showed positive results. Although the patient's outcome following re-operation was not described in one case, re-operation was successfully completed in the remaining six cases by avoiding the drug that tested positive in early skin tests. Further, in two of the cases who subsequently underwent a second skin test, test results were consistent with those of the first skin tests (Table 3).

Taken together, waiting for 4-6 weeks in accordance with the guidelines might not be possible in cases that require a rapid diagnosis. If early skin tests show positive reactions to any of the culprit drugs, avoiding these drugs during subsequent anesthesia would be acceptable. Conversely, no previous reports have described safe second anesthesia using the suspected drug(s) when all the drugs tested showed negative reactions in early skin tests. Thus, as far as possible, all suspected drugs should be avoided in such situations.

We performed BATs in addition to skin tests after reoperation. Although skin tests remain the gold standard for detection of the culprit drug, the positive predictive value of skin tests is not $100 \%$. Hence, there seems to be room for other tests, including BATs. Since BATs are in vitro tests, the risks and burden on patients are minimal. Given the high specificity of BATs for neuromuscular blocking agents (NMBAs) (between 81 and 100\% [24]), the combination of BATs and skin tests would allow diagnosis of anaphylaxis with high accuracy [25].

A pivotal factor in interpreting the results of skin tests is the cross-reactivity between drugs. We did not use any NMBAs for the second anesthesia, because rocuronium exhibits cross-reactivity with alternative NMBAs [26, 27]. For example, an Australian study demonstrated that patients with rocuronium anaphylaxis were skin test positive to succinylcholine (44\%) and vecuronium (40\%) [26]. Since there are only three NMBAs currently available in Japan, we do not have much of a choice for safer alternatives if anaphylaxis occurs with any of these NMBAs. Indeed, the second skin tests showed that rocuronium was the cause of anaphylaxis in our case. If this patient needs to be anesthetized in future, the only option would be to not use an NMBA. This is a common problem faced by Japanese anesthesiologists. The introduction of benzylisoquinoliniums, such

Table 3 Case reports in which early skin tests showed positive results to any of the drugs tested

\begin{tabular}{|c|c|c|c|c|c|c|c|c|c|c|c|}
\hline \multirow{2}{*}{$\begin{array}{l}\text { Case } \\
\text { number }\end{array}$} & \multirow[t]{2}{*}{ Age } & \multirow[t]{2}{*}{ Sex } & \multirow[t]{2}{*}{ Procedure } & \multirow{2}{*}{$\begin{array}{l}\text { Culprit } \\
\text { drug }\end{array}$} & \multicolumn{2}{|c|}{ First skin tests } & \multicolumn{2}{|c|}{ Subsequent surgery } & \multicolumn{2}{|c|}{ Second skin tests } & \multirow{2}{*}{$\begin{array}{l}\text { Reference } \\
\text { number }\end{array}$} \\
\hline & & & & & Delay & Results & Delay & Outcome & Delay & Results & \\
\hline 1 & 17 & $\mathrm{~F}$ & $\begin{array}{l}\text { Cholecystec- } \\
\text { tomy }\end{array}$ & $\begin{array}{l}\text { Rocuro- } \\
\text { nium }\end{array}$ & 1 day & IDT $1: 1000+$ & 2 days & Uneventful $\dagger$ & 10 weeks & $\begin{array}{l}\text { Skin test- } \\
\text { ing }+\end{array}$ & 18 \\
\hline 2 & 52 & M & $\begin{array}{l}\text { Temporal } \\
\text { lobectomy } \\
\text { for treatment } \\
\text { of poorly } \\
\text { controlled } \\
\text { epilepsy }\end{array}$ & $\begin{array}{l}\text { Chlorhex- } \\
\text { idine }\end{array}$ & 2 days & $\begin{array}{l}\text { SPT } 0.2 \%+\text {, } \\
\text { IDT } \\
1: 1000+\end{array}$ & $\begin{array}{l}\text { Not } \\
\text { described }\end{array}$ & Uneventful $†$ & ND & & 19 \\
\hline 3 & 58 & $\mathrm{~F}$ & $\begin{array}{l}\text { Resection of } \\
\text { rectal cancer }\end{array}$ & $\begin{array}{l}\text { Rocuro- } \\
\text { nium }\end{array}$ & 3 days & IDT $1: 1000+$ & 7 days & Uneventful $\dagger$ & ND & & 20 \\
\hline 4 & 68 & M & $\begin{array}{l}\text { Mediastinos- } \\
\text { copy to stage } \\
\text { a carcinoma } \\
\text { of the lung }\end{array}$ & $\begin{array}{l}\text { Rocuro- } \\
\text { nium }\end{array}$ & 4 days & SPT $1: 1+$ & 7 days & Uneventful $†$ & ND & & 6 \\
\hline 5 & 59 & M & $\begin{array}{l}\text { Resection of } \\
\text { rectal cancer }\end{array}$ & $\begin{array}{l}\text { Cisatracu- } \\
\text { rium }\end{array}$ & 7 days & $\begin{array}{l}\text { IDT } 0.02 \\
\mathrm{mg} / \mathrm{ml}+\end{array}$ & 10 days & Uneventful $\dagger$ & 6 weeks & $\begin{array}{l}\text { SPT } \\
\begin{array}{l}2 \mathrm{mg} / \\
\mathrm{ml}+\end{array}\end{array}$ & 21 \\
\hline 6 & 53 & $\mathrm{~F}$ & $\begin{array}{l}\text { Excision of } \\
\text { breast cancer }\end{array}$ & $\begin{array}{l}\text { Isosulfan } \\
\text { blue }\end{array}$ & 10 days & $\mathrm{SPT}+$ & Not described & & ND & & 22 \\
\hline 7 & 70 & M & $\begin{array}{l}\text { Partial nephrec- } \\
\text { tomy }\end{array}$ & $\begin{array}{l}\text { Cisatracu- } \\
\text { rium }\end{array}$ & 14 days & SPT 1:1000+ & 3 months & Uneventful $\dagger$ & ND & & 23 \\
\hline
\end{tabular}

Case 1: Since the patient was soon to have final school exams, her family desired that her illness be resolved as quickly as possible

Case 7: The surgery was changed to total nephrectomy after the first skin tests

$F$ female; $M$ male; $S P T$ skin prick test; IDT intradermal test; $N D$ tests not performed

${ }^{\dagger}$ After the first surgery was postponed, the subsequent surgery could be completed without any problem by avoiding the drugs that showed positive results on the first skin tests 
as cisatracurium, in Japan is expected, because they are reported to have low cross-reactivity with rocuronium (5\%) [26]. In fact, safe use of benzylisoquinoliniums in patients with rocuronium-induced anaphylaxis has been reported in a country where these drugs are available [28].

After postponement of surgery due to anaphylaxis, we are often required to perform allergy tests at an early stage when re-operation cannot be delayed. In such cases, skin test results alone should not be used to guide subsequent anesthesia management to avoid recurrent anaphylaxis.

Funding This manuscript was supported by JSPS KAKENHI Grant Numbers 17K16721 and 18K08809.

\section{Compliance with ethical standards}

Competing interests The authors declare that they have no competing interests.

Open Access This article is licensed under a Creative Commons Attribution 4.0 International License, which permits use, sharing, adaptation, distribution and reproduction in any medium or format, as long as you give appropriate credit to the original author(s) and the source, provide a link to the Creative Commons licence, and indicate if changes were made. The images or other third party material in this article are included in the article's Creative Commons licence, unless indicated otherwise in a credit line to the material. If material is not included in the article's Creative Commons licence and your intended use is not permitted by statutory regulation or exceeds the permitted use, you will need to obtain permission directly from the copyright holder. To view a copy of this licence, visit http://creativecommons.org/licenses/by/4.0/.

\section{References}

1. Simons FE, Ebisawa M, Sanchez-Borges M, Thong BY, Worm M, Tanno LK, Lockey RF, El-Gamal YM, Brown SG, Park HS, Sheikh A. 2015 update of the evidence base: World Allergy Organization anaphylaxis guidelines. World Allergy Organ J. 2015;8:32.

2. Dewachter P, Mouton-Faivre C, Emala CW. Anaphylaxis and anesthesia: controversies and new insights. Anesthesiology. 2009;111:1141-50.

3. Mertes PM, Malinovsky JM, Jouffroy L; Working Group of the SFAR and SFA, Aberer W, Terreehorst I, Brockow K, Demoly P; ENDA; EAACI Interest Group on Drug Allergy. Reducing the risk of anaphylaxis during anesthesia: 2011 updated guidelines for clinical practice. J Investig Allergol Clin Immunol. 2011;21:442-53.

4. Harper NJ, Dixon T, Dugué P, Edgar DM, Fay A, Gooi HC, Herriot R, Hopkins P, Hunter JM, Mirakian R, Pumphrey RS, Seneviratne SL, Walls AF, Williams P, Wildsmith JA, Wood P, Nasser AS, Powell RK, Mirakhur R, Soar J; Working Party of the Association of Anaesthetists of Great Britain and Ireland. Suspected anaphylactic reactions associated with anaesthesia. Anaesthesia. 2009;64:199-211.

5. Ewan PW, Dugué P, Mirakian R, Dixon TA, Harper JN, Nasser SM; BSACI. BSACI guidelines for the investigation of suspected anaphylaxis during general anaesthesia. Clin Exp Allergy. 2010;40:15-31.

6. Soetens F, Rose M, Fisher M. Timing of skin testing after a suspected anaphylactic reaction during anaesthesia. Acta Anaesthesiol Scand. 2012;56:1042-6.

7. Fisher MM, Merefield D, Baldo B. Failure to prevent an anaphylactic reaction to a second neuromuscular blocking drug during anaesthesia. Br J Anaesth. 1999;82:770-3.

8. Fraser BA, Smart JA. Anaphylaxis to cisatracurium following negative skin testing. Anaesth Intensive Care. 2005;33:816-9.

9. Dewachter P, Mouton-Faivre C. What investigation after an anaphylactic reaction during anaesthesia? Curr Opin Anaesthesiol. 2008;21:363-8.

10. Horiuchi T, Yokohama A, Orihara M, Tomita Y, Tomioka A, Yoshida N, Takahashi K, Saito S, Takazawa T. Usefulness of basophil activation tests for diagnosis of sugammadex-induced anaphylaxis. Anesth Analg. 2018;126:1509-16.

11. Horiuchi T, Takazawa T, Orihara M, Sakamoto S, Yokohama A, Takahashi J, Tomioka A, Yoshida N, Hagiwara K, Saito S. Required cefazolin concentration to maximize diagnostic accuracy of the basophil activation test for cefazolin-induced anaphylaxis. J Anesth. 2018;32:797-805.

12. Takazawa T, Horiuchi T, Yoshida N, Yokohama A, Saito S. Flow cytometric investigation of sugammadex-induced anaphylaxis. $\mathrm{Br}$ J Anaesth. 2015;114:858-9.

13. Renaudin JM, Beaudouin E, Ponvert C, Demoly P, Moneret-Vautrin DA. Severe drug-induced anaphylaxis: analysis of 333 cases recorded by the allergy vigilance network from 2002 to 2010 . Allergy. 2013;68:929-37.

14. Lafuente A, Javaloyes G, Berroa F, Goikoetxea MJ, Moncada R, Núñez-Córdoba JM, Cabrera-Freitag P, D’Amelio C, Sanz ML, Gastaminza G. Early skin testing is effective for diagnosis of hypersensitivity reactions occurring during anesthesia. Allergy. 2013;68:820-2.

15. Fisher MM. Intradermal testing after severe histamine reactions to intravenous drugs used in anaesthesia. Anaesth Intensive Care. 1976;4:97-104.

16. Culp JA, Palis RI, Castells MC, Lucas SR, Borish L. Perioperative anaphylaxis in a 44-year-old man. Allergy Asthma Proc. 2007;28:602-5.

17. Aalto-Korte K, Makinen-Kiljunen S. False negative SPT after anaphylaxis. Allergy. 2001;56:461-2.

18. Schulberg EM, Webb AR, Kolawole H. Early skin and challenge testing after rocuronium anaphylaxis. Anaesth Intensive Care. 2016;44:425-7.

19. Russ BR, Maddern PJ. Anaphylactic reaction to chlorhexidine in urinary catheter lubricant. Anaesth Intensive Care. 1994;22(5):611-2.

20. Kubitz JC, Krause T, Dietz R, Friederich P, Goetz AE. Severe anaphylaxis from rocuronium. Anaesthesist. 2006;55:1169-71.

21. Goikoetxea MJ, Lafuente A, de la Borbolla JM, Moncada R, Sanz ML, Gastaminza G. Early diagnosis of an allergic reaction to cisatracurium. J Investig Allergol Clin Immunol. 2013;23:69-71.

22. Sprung J, Tully MJ, Ziser A. Anaphylactic reactions to isosulfan blue dye during sentinel node lymphadenectomy for breast cancer. Anesth Analg. 2003;96:1051-3.

23. Ya-Ling Yang H-WH, Yip H-K, Jawan B, Tseng C-C, HsiaoFeng L. Acute coronary syndrome in cisatracurium-induced anaphylactic shock: kounis syndrome. Acta Anaesthesiol Taiwan. 2008;46:184-6.

24. Ebo DG, Faber M, Elst J, Van Gasse AL, Bridts CH, Mertens C, De Clerck LS, Hagendorens MM, Sabato V. In vitro diagnosis of immediate drug hypersensitivity during anesthesia: a review of the literature. J Allergy Clin Immunol Pract. 2018;6:1176-84. 
25. Takazawa T, Sabato V, Ebo DG. In vitro diagnostic tests for perioperative hypersensitivity, a narrative review: potential, limitations, and perspectives. Br J Anaesth. 2019;123(1):e117-e125.

26. Sadleir PH, Clarke RC, Bunning DL, Platt PR. Anaphylaxis to neuromuscular blocking drugs: incidence and cross-reactivity in Western Australia from 2002 to 2011. Br J Anaesth. 2013;110:981-7.

27. Tacquard C, Collange O, Gomis P, Malinovsky JM, Petitpain N, Demoly P, Nicoll S, Mertes PM. Anaesthetic hypersensitivity reactions in France between 2011 and 2012: the 10th GERAP epidemiologic survey. Acta Anaesthesiol Scand. 2017;61:290-9.

28. Leysen J, Uyttebroek A, Sabato V, Bridts CH, De Clerck LS, Ebo DG. Predictive value of allergy tests for neuromuscular blocking agents: tackling an unmet need. Clin Exp Allergy. 2014;44:1069-75.

Publisher's Note Springer Nature remains neutral with regard to jurisdictional claims in published maps and institutional affiliations. 